DOI: 10.17148/IARJSET.2021.8957

\title{
A STUDY ON WORK LIFE BALANCE AMONG WOMEN FACULTY MEMBERS WORKING IN PRIVATE COLLEGES SPOTLIGHT ON SOUTH INDIA'S MANCHESTER CITY
}

\author{
Nirmala Shiny. P $^{1}$, Dr. S. Ramkumar ${ }^{2}$ \\ ${ }^{1}$ Research Scholar, Bharathiyar University \\ ${ }^{2}$ Associate Professor, Department of Management Science, Kongunadu Arts and Science College, Coimbatore
}

\begin{abstract}
The success of any educational institution is primarily determined by the pass percentage of students and the placement record of the institution. Thus, in order to mould students in the right way, the role of teachers is very important. Teaching faculty can contribute their full potential and efficiency for the development of their pupils, while they derive high level of job satisfaction. Job satisfaction, in turn depends on an efficient way of managing their work and family commitments. So, in this study, an attempt has been made to identify the factors influencing work and life balance and to examine the ways in which teaching faculty manage their work and life balance. The result of the study exhibits that age, the number of elders in their family, the amount of monthly income earned and number of years of experience. Furthermore, the results of the study disclose that women faculty, by working extra time, in case of need, try to complete the work in time.
\end{abstract}

Keywords: Educational institution, job satisfaction, work life balance

\section{INTRODUCTION}

A good balance between work and life is possible, only when there is a conducive atmosphere both at home and the work place. In India with its changing socio-cultural environment and an augment in educational opportunities, women have started understanding their intrinsic ability. Higher education not only augments employment opportunities and growth of GDP in a country, but also contributes to cultural changes and social rebellion. Nowadays, Indian women, who were earlier believed to be fit only for a socially acceptable employment like teaching, nursing and banking, have now enthusiastically invaded other fields. However, in the prevalent family and communal group, women teaching faculty are overstrained and find it hard to balance their work and life. In the human capital framework, knowledge and skills are specific forms.

As a result, women staff members find it hard to achieve work-life balance. The profession, with its superior salary, cultural and social changes in the society, has brought change among the teachers in Arts and Science colleges. While general education is knowledge-oriented, higher education is skill-oriented. The former is portable across one's life and from job to job, while the latter is not, and hence many advocates general education, as more suitable to the flexible labour force that can change task and even the type of work. But the latter has an advantage, imbibing specific job relevant skills that can make the worker more readily suitable for a given job and can also help women become more productive. Hence, both are significant and education systems in many countries comprise general and higher education requiring varying skill levels. Women in India are typically climbing the career ladder at work, caring for challenging adolescent children at home and at their working place. All these pressures increase the strain among women staff members on managing their work and life commitments and try to ascertain methods to overcome the strains of a busy life style, family and social life. Thus, in this study an attempt has been made to ascertain the factors associated with work life balance of female faculty working at Arts and Science Colleges in Coimbatore district and to examine the methods followed by them for managing their work and life commitments. 
The significance concerns with work life balance among women faculties. It may also yield some discoveries concerning individuals' abilities to achieve work life balance while managing a career as an institutional advancement professional. This information may encourage changes in policy and practice within their workplaces or those of other institutions. Additionally, as turnover of faculty in this profession continues to be a problem (Collins, 2002), it was hopeful that this study definitely identifies reasons why faculty leave their positions and reveals some strategies to reverse the trend. Several groups may be interested in the results and conclusions of this research study. They include institutional such as academic institutions and universities, institutional advancement, and other development professionals who are striving to achieve work life balance in their lives. Further, this research study highlights the role of working women and their balancing of work and personal life. The role and participation of women both in family and social lives are inevitable.

\section{OBJECTIVES OF THE STUDY}

\section{Primary objective}

To study the work - life balance of women faculties

Secondary Objective

- $\quad$ To study the demographic and socio - economic status of women faculties working in college

- $\quad$ To study the attitude towards the work - life balance of women faculty working in college

- $\quad$ Factors influencing the satisfaction of the women faculty.

- $\quad$ To study the work environment of the faculty.

- To identify the constrains faced by the women faculty and their impact towards their performance.

Limitations of the Study

The study is undertaken with the following limitations

- $\quad$ The study is undertaken to limited samples only focused women faculties.

- $\quad$ Long working hours effect the efficiency women of faculty members.

- Implementing a work life balance takes times.

\section{REVIEW OF LITERATURE}

Niharika and Supriya (2010) in their study identified part time and liberty, the flexible working time, provision of opportunity to work from home and permitting women employees to take care of children's in case of emergencies matter much in work - life balance.

Santhana Lakshmi et al., (2013) in their study ascertain that the educational institutions should deal with WLB related problems that prevail among staff members and take a holistic approach to plan and execute the strategies to help the staffs in managing WLB.

Sudha and Dr. P. Karthikeyan (2014) in their study ascertain that women faculty, by proper scheduling of work and fixing the time limits for each and every work, can very well manage personal and professional life.

Nayeem A., Tripathy M (2012) in the paper titled "Work-Life Balance among Teachers " in their study mentioned that teaching is reported to have positive and negative experiences about work- life. Their paper has examined the job relationship of job satisfaction with work balance

\section{RESEARCH METHODOLOGY}

Research design proposed for the study is descriptive type of research. This type of research deals with the quality of responses from the respondents, attitudes, interests, technical skills, experience, behavioral, beliefs and values, emotions, personality, self-concept etc.

\section{- Primary data}

Primary data was circulated by the questionnaire to the female faculty of different college to analyze the various aspects of work - life balance of female teaching professionals

\section{- Secondary data}

Secondary data was collected from journals, books and research articles to support the research.

Statistical Tools and Techniques

- Chi - square

Chi square is a method used in statistics that calculates the difference between observed and expected data values. It is used to determine how closely actual data fit expected data. 
Formula

$$
\chi_{c}^{2}=\sum \frac{\left(O_{i}-E_{i}\right)^{2}}{E_{i}}
$$

\section{DATA ANALYSIS AND INTERPRETATION}

\section{Chi-Square Test}

To test the relationship between balancing work life of the respondents and respondents who do not get affected due to stress

- Null Hypothesis $\left(\mathbf{H}_{\mathbf{0}}\right)$ : There is no association between balancing work life of the respondents and respondents who do not get affected due to stress.

- $\quad$ Alternative Hypothesis $\left(\mathbf{H}_{1}\right)$ : There is an association between balancing work life of the respondents and respondents who do not get affected due to stress.

- $\quad$ P value $=0.5$

\begin{tabular}{|l|l|l|l|l|l|l|l|}
\hline \multirow{2}{*}{ S. No } & Bwl & $\begin{array}{l}\text { Strongly } \\
\text { agree }\end{array}$ & Agree & Neutral & Disagree & $\begin{array}{l}\text { Strongly } \\
\text { disagree }\end{array}$ & Total \\
\cline { 2 - 7 } & Ads & & & & & & \\
\hline 1 & Yes & 10 & 37 & 25 & 11 & 4 & 87 \\
\hline $\mathbf{2}$ & No & 0 & 2 & 3 & 5 & 3 & 13 \\
\hline \multicolumn{1}{l}{ Total } & $\mathbf{1 0}$ & $\mathbf{3 9}$ & $\mathbf{2 8}$ & $\mathbf{1 6}$ & $\mathbf{7}$ & $\mathbf{1 0 0}$ \\
\hline
\end{tabular}

- Bwl - balancing work life of the respondents

- $\quad$ Ads- affected due to stress

\begin{tabular}{|l|l|l|l|}
\hline $\begin{array}{l}\text { Calculated value } \\
\text { Chi-square value }\end{array}$ & $\begin{array}{l}\text { Degree } \\
\text { freedom }\end{array}$ & Probability level & $\begin{array}{l}\text { Critical chi-square } \\
\text { value }\end{array}$ \\
\hline 13.989 & 4 & 0.05 & .007 \\
\hline
\end{tabular}

- Interpretation

- It is found from the above table that the significant value obtained is 0.007 which is less than 0.05 , Alternative Hypothesis is accepted.

- $\quad$ Hence, there is an association between the balancing work and life of the respondents and respondents who do not get affected due to stress.

To test the relationship between respondents who engage in stress related activities and the respondents who balance the quality time both in personal and work life

- $\quad$ Null Hypothesis $\left(\mathbf{H}_{0}\right)$ : There is no association with the respondents who engage in stress related activities and the respondents who balance the quality time both in personal and work life.

- $\quad$ Alternative Hypothesis (H1): There is an association with the respondents who engage in stress related activities and the respondents who balance the quality time both in personal and work life.

$\boldsymbol{P}$ value $=\mathbf{0}$.

\begin{tabular}{|l|l|l|l|l|l|l|l|}
\hline S. No & $\begin{array}{l}\text { Sra } \\
\text { Pwl }\end{array}$ & $\begin{array}{l}\text { Strongly } \\
\text { agree }\end{array}$ & Agree & Neutral & Disagree & $\begin{array}{l}\text { Strongly } \\
\text { disagree }\end{array}$ & Total \\
\hline 1 & Yes & 23 & 21 & 16 & 7 & 1 & 68 \\
\hline 2 & No & 0 & 15 & 8 & 5 & 4 & 32 \\
\hline Total & $\mathbf{2 3}$ & $\mathbf{3 6}$ & $\mathbf{2 4}$ & $\mathbf{1 2}$ & $\mathbf{5}$ & $\mathbf{1 0}$ \\
\hline $\begin{array}{l}\text { Calculated value } \\
\text { Chi-square value }\end{array}$ & Degree of freedom & \multicolumn{2}{|l|}{ Probability level } & $\begin{array}{l}\text { Critical chi square } \\
\text { value }\end{array}$ \\
\hline 18.199 & 3 & 0.05 & .001 & \\
\hline
\end{tabular}




\section{International Advanced Research Journal in Science, Engineering and Technology}

Vol. 8, Issue 9, September 2021

DOI: $10.17148 /$ IARJSET.2021.8957

\section{Sra- Stress related activities}

\section{Pwl- Personal and work life of the respondents.}

\section{Interpretation}

It is found from the above table that the significant value obtained is 0.001 which is less than 0.05 , Alternative Hypothesis is accepted.

Hence, there is an association between the respondents who engage in stress related activities and the respondents who balance the quality time both in personal and work life.

\section{FINDINGS}

- $\quad$ The majority of respondents (39\%) feels they are not affected in work, due to the behavioral disturbances faced in their home.

- $\quad$ The majority of respondents (39\%) feels they are not affected in work, due to the stress faced in their home

- $\quad$ There exists significant association between the balancing work and life of the respondents and respondents who do not get affected due to stress.

- $\quad$ There exists significant association between the respondents who engage in stress related activities and the respondents who balance the quality time both in personal and work life.

\section{SUGGESTIONS}

- $\quad$ The study showed that majority of the teachers think about work even when not at work which discourages work life balance and builds up stress. So, the teachers must learn to forget work related things when not at work to improve their work life balance.

- $\quad$ The teachers should make time for work and life in equal proportions to find the optimum level of balance between work and life.

- $\quad$ The study showed that having a hobby or taking part in extracurricular activities strengthens the relationship between work and life. Therefore, the teachers should find themselves a hobby or take part in extracurricular activities that acts as a reset button to refresh their minds and clear it up for other work-related issues to maintain a balance between work and life.

\section{CONCLUSION}

The growing diversity of family structures represented in the workforce, including dual earner couples, single parents, blended families, employees with elder care responsibilities and the increasing number or people choosing to live alone, has heightened the relevance of balancing work and life roles for a substantial segment of employed women.

\section{BIBLIOGRAPHY}

\section{Books}

- Q "Quality of Work life of women”, Discovery Publishing House, New Delhi.

- $\quad$ "India’s educated women: Options and Constraints”, Hindustan Publishing Corporation, New Delhi.

- "QQuality of reduction of working hour", Groningen, Karstapel.

\section{REFERENCES}

Maharaj A. (2015) "HR Interventions for Work Life Balance” International 3, pp.20-26, 2014.

Santosh R. S., Jain R. (2016) Demographic Predictors of Work Family Conflict for Men and Women: Turkish Case, International Journal of Business and Management, Vol. 7 (13), pp $145-158$.

Nayeem A and Tripathy (2012) Work and Family Conflicts and Family - Work Conflicts, Pakistan Business Review, Vol. 13 (2), pp 315 - 331. Meharaj. A (2015) All in a Day's Work: Boundaries and Micro Role Transitions, Academy of Management Review, Vol. 25 (3), pp 472 - 491. Lindhak Jhonsrud (2002) Changing Families, Changing Workplaces, The Future of Children, Vol. 21 (2), pp 15 - 36.

\section{WEBSITES}

Shodhganga.inflibnet.ac.in www.readperiodicals.com. 